\title{
Pursuit of the ideal antiseptic irrigation solution in the management of periprosthetic joint infections
}

\author{
Ahmed Siddiqi ${ }^{1,2,3}$, Zuhdi E. Abdo ${ }^{4}$, Bryan D. Springer ${ }^{5}$, and Antonia F. Chen ${ }^{6}$ \\ ${ }^{1}$ Orthopaedic Institute of Central Jersey, a division of Ortho Alliance NJ, \\ 2315 Route 34 South Manasquan, NJ 08736, USA \\ ${ }^{2}$ Hackensack Meridian School of Medicine, Department of Orthopedic Surgery, Hackensack, NJ, USA \\ ${ }^{3}$ Jersey Shore University Medical Center, Department of Orthopedic Surgery, Neptune, NJ, USA \\ ${ }^{4}$ Rutgers New Jersey Medical School, Department of Orthopedics, Newark, NJ, 07103, USA \\ ${ }^{5}$ OrthoCarolina Hip and Knee Center, Department of Orthopedics Atrium Musculoskeletal Institute, \\ Charlotte, NC, 28207, USA \\ ${ }^{6}$ Brigham \& Women's Hospital, Department of Orthopedics, Boston, MA, 02115, USA \\ Correspondence: Ahmed Siddiqi (asiddiqi89@gmail.com)
}

Received: 18 March 2021 - Revised: 6 May 2021 - Accepted: 7 May 2021 - Published: 26 May 2021

\begin{abstract}
Irrigation and debridement in the treatment of periprosthetic joint infection (PJI) serve an integral role in the eradication of bacterial burden and subsequent re-infection rates. Identifying the optimal irrigation agent, however, remains challenging, as there is limited data on superiority. Direct comparison of different irrigation solutions remains difficult because of variability in treatment protocols. While basic science studies assist in the selection of irrigation fluids, in vitro results do not directly translate into clinical significance once implemented in vivo. Dilute povidone iodine, hydrogen peroxide, chlorhexidine gluconate, acetic acid, sodium hypochlorite, hypochlorous acid, and preformed combination solutions all have potential against a broad spectrum of PJI pathogens with their own unique advantages and disadvantages. Future clinical studies are needed to identify ideal irrigation solutions with optimal bactericidal properties and low cytotoxicity for PJI treatment.
\end{abstract}

Periprosthetic joint infection (PJI) and surgical site infection (SSI) remain common and devastating complications after total joint arthroplasty (TJA) (Sloan et al., 2018). Although two-stage revision arthroplasty is considered the gold standard treatment for PJI, debridement, antibiotics, and implant retention (DAIR) as well as one-stage revision arthroplasty may be considered in certain situations in effort to decrease morbidity and mortality associated with additional surgical procedures. However, thorough irrigation and debridement of infectious tissue remains the most critical portion of any of the surgical options for acute and chronic PJI.

The use of multiple additives with normal saline solution irrigation to improve bacterial bioburden eradication is increasing. The optimal irrigation solution should have minimal toxicity while maintaining bactericidal and fungi- cidal activity at its minimum biofilm eradication concentration (MBEC), which is defined as the lowest concentration needed to diminish the biofilm by $99.9 \%$ (Van Meurs et al., 2014). Additives are divided into three categories: surfactants, antibiotics, and antiseptics. Surfactants contain detergents, such as castile soap or benzalkonium chloride. Antibiotic irrigation most commonly contains bacitracin and/or polymyxin. Antiseptic solutions include povidone iodine, chlorhexidine gluconate (CHG), hydrogen peroxide, sodium hypochlorite, acetic acid, hypochlorous acid, and combination solutions (Table 1). Identifying the ideal irrigation solution remains challenging, however, as there is limited data on superiority.

Although high-quality clinical trials exploring surfactant irrigation in PJI management are scarce, the Center for Disease Control (CDC), World Health Organization (WHO), National Institute for Health and Care Excellence (NICE), 


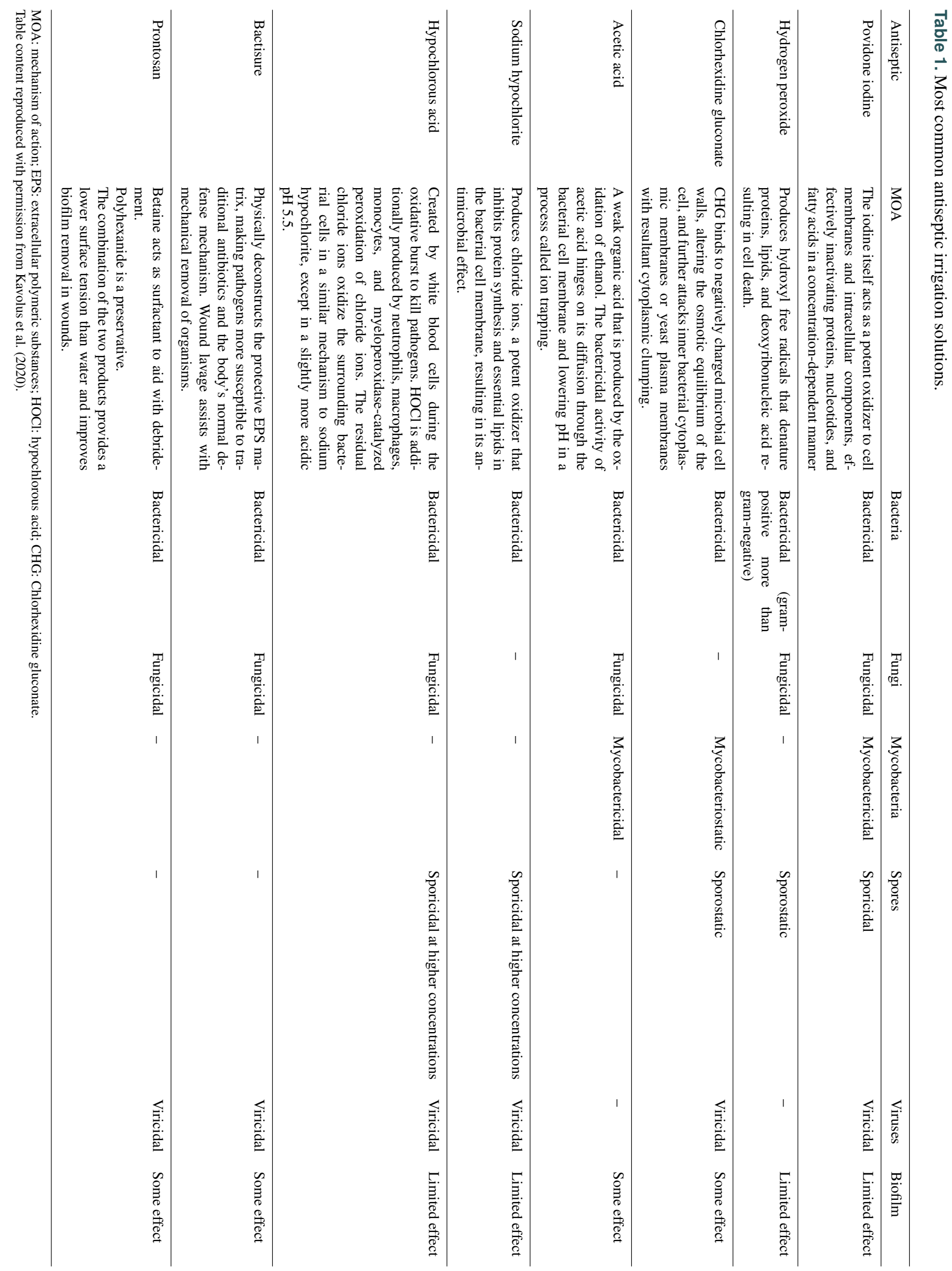


and 2018 international consensus meeting (ICM) on musculoskeletal infections recommend against the use of antibiotic irrigation in PJI and SSI prevention and treatment (Blom et al., 2019). More recently, the Food and Drug Administration (FDA) has requested withdrawal of bacitracin injections due to high risk of anaphylaxis and complications (FDA, 2020). Furthermore, there are no clear guidelines regarding the optimal irrigation type, amount, or protocol for management of acute or chronic PJI. The purpose of this comprehensive review is to evaluate commercially available antiseptic irrigation solutions and their clinical outcomes and complications for the management of PJI.

\section{Povidone iodine}

Povidone iodine functions as a powerful oxidizer to cell membranes and inactivates intracellular contents in a concentration-dependent method (Ruder and Springer, 2016). Although clinical practice guidelines from the WHO and ICM recommend sterile povidone iodine for the prevention of SSI (Blom et al., 2019; World Health Organization, 2018) there are no guidelines regarding povidone iodine's role in definitive PJI management. The ICM, however, does support the utilization of dilute povidone iodine with a "super majority, strong consensus" during DAIR procedures without further specifying optimal dilution concentrations (Blom et al., 2019). While some studies suggest povidone iodine to be very effective with minimal damage to host tissue at lower concentrations (Rabenberg et al., 2002) other studies report toxicity regardless of concentration (Foresman et al., 1993).

Different povidone-iodine concentrations have been tested against various organisms to determine bactericidal activity relative to host cell viability (Ruder and Springer, 2016). At higher concentrations (20\%), PI has toxicity against human fibroblast cells (Rabenberg et al., 2002). Therefore, dilution is necessary to mitigate PI toxicity to host tissue. However, the optimal PI dilution has yet to be determined. PI is commercially available at $100 \mathrm{~g} / \mathrm{L}(10 \%)$, which is both bactericidal and cytotoxic (Ruder and Springer, 2016; Van Meurs et al., 2014).

\subsection{Outcomes}

A povidone iodine solution (10\%) has been shown to have efficacy against methicillin-sensitive Staphylococcus aureus (MSSA) biofilm grown on plastic, cement, and porous titanium with minimal effectiveness of dilute $0.35 \%$ povidone iodine (Premkumar et al., 2020). However, in another in vitro analysis, Goswami et al. (2019) reported $0.3 \%$ povidone iodine to have adequate eradication of MSSA and Escherichia coli biofilm with minimal cytotoxicity against human osteoblasts, chondrocytes, and fibroblasts. Other studies have shown povidone irrigation's ability to remove common PJI bacteria biofilm (including MRSA, MSSA, Staphylococcus epidermidis, Haemophilus influenzae, Pseudomonas aeruginosa, and E. coli) on orthopaedic materials such as stainless-steel screws, titanium discs, and polyethylene washers (Cichos et al., 2019; Gilotra et al., 2015). There is also no study, to our knowledge, that reports identifiable acquired bacterial resistance or cross-resistance which would make povidone iodine an appealing irrigant adjuvant in PJI treatment.

Recently, Riesgo et al. (2018) compared the utility of dilute povidone-iodine irrigation with vancomycin powder for 20 total hip arthroplasty (THA) and 16 total knee arthroplasty (TKA) PJI cases compared to a matched cohort of patients managed with normal saline without antibiotic powder. The authors reported $83.3 \%$ (30 out of 36) success rate of the povidone-iodine and vancomycin cohort compared to $63.2 \%$ (24 out of 38 ) success of the control group at 27 -month follow-up. Although the re-infection rates were not statistically different between the two groups $(0=0.32)$, the povidone-iodine cohort had a $45 \%$ relative risk reduction and overall DAIR success rate improvement from $63 \%$ to $83.3 \%$. Currently there is a multicenter, prospective, randomized-controlled trial evaluating vancomycin powder, povidone iodine alone, vancomycin-povidone-iodine combination, and saline in the prevention of PJI. The outcomes of the study may help guide future management of PJI.

\subsection{Complications}

Several studies have raised concerns regarding povidone iodine's cytotoxic effects on human tissue including osteoblasts, myoblasts, chondrocytes, and fibroblasts; however, this in vitro concern has not translated into in vivo studies (Goswami and Austin, 2019a). Povidone iodine has also raised concerns from increasing patient-reported iodine allergies including anaphylaxis (Waran and Munsick, 1995).

Additionally, various factors have been associated with povidone-iodine contamination as multiple organisms, including Burkholderia cepacia, P. aeruginosa, Mycobacterium abscessus, and fungal pathogens, have been reported to be found in aqueous povidone iodine, either directly from the packaged bottles or from dilution with non-sterile saline (Goswami and Austin, 2019b). Recently in October 2020, the Food and Drug Administration (FDA) approved the first sterile commercially available dilute povidone-iodine solution (Surgiphor Wound Irrigation System, Parvizi Surgical Innovation, Philadelphia, PA) for clinical utilization (Surgiphor Wound Irrigation System FDA, 2021). Finally, surgeons who inject liposomal bupivacaine for multimodal analgesia should be cognizant that povidone-iodine lyses liposomes, thereby removing its slow-release effect (Ruder and Springer, 2016). Povidone-iodine irrigation should, therefore, be utilized prior to administration of liposomal bupivacaine. 


\section{Hydrogen peroxide}

Hydrogen peroxide produces free radicals that denature proteins, lipids, and deoxyribonucleic acid (DNA) resulting in bacterial and fungal cell death. It is organically present within human tissues and serves diverse roles in the host innate immune response to infection ( $\mathrm{Lu}$ and Hansen, 2016). It has been proven effective against viruses, bacteria, yeasts, and bacterial spores, with its greatest bactericidal affects against gram-positive organisms (Lu and Hansen, 2016). Hydrogen peroxide's foam further aids in mechanical wound debridement without detrimental effects on the strength of bone-cement interfaces or metal implants, which is critical during acute PJI and DAIR procedures (Lu and Hansen, 2016).

\subsection{Clinical outcomes}

Multiple in vitro studies have shown hydrogen peroxide's ability to reduce a broad spectrum of bacterial biofilm (Glynn et al., 2009; Lu and Hansen, 2016). Glynn et al. (2009) found that different concentrations of hydrogen peroxide (5, $10 \mathrm{mM}$ ) inhibited biofilm development by Staphylococcus epidermidis compared to an untreated control group. Zubko and Zubko (2013) reported the synergistic effect of hydrogen peroxide and povidone iodine concurrently against 3 bacterial (S. aureus, Pseudomonas aeruginosa, E. coli) and 16 fungal pathogens and found hydrogen peroxide and povidone iodine to be bacteriostatic when used separately and bactericidal when used in conjunction. Synergistic utilization of hydrogen peroxide with other antiseptic solutions has the potential to treat a broader spectrum of pathogens at lower cytotoxic concentrations of each individual solution (Zubko and Zubko, 2013). Further in vivo studies are needed to investigate the role of hydrogen peroxide alone and its synergistic effects with other antiseptic irrigating solutions in PJI management.

\subsection{Complications}

Despite some host cytotoxic effects reported in in vitro investigations, no in vivo studies have shown deleterious effect on host tissues or wound healing. The breakdown of hydrogen peroxide into oxygen gas, however, increases the risk of air embolism, with reports of cardiac arrest in the literature (Henley et al., 2004). Thorough irrigation with normal saline is recommended after hydrogen-peroxide utilization to mitigate such complications.

\section{Chlorhexidine gluconate}

CHG is a cationic bisbiguanide that binds to bacterial and fungal cell walls and alters the intracellular osmotic equilibrium (George et al., 2017). CHG is highly effective against a broad spectrum of pathogens responsible for PJI including
MSSA, MRSA, coagulase negative Staphylococcus (CNS), gram-negative bacteria, and fungi (George et al., 2017). CHG's bactericidal effect is almost immediate with host tissue contact, with the greatest uptake occurring within $20 \mathrm{~s}$ of exposure. Its duration of effect is directly related to both the length of exposure and solution concentration (Weinstein et al., 2008). The FDA recently approved a dilute CHG formulation $(0.05 \%$ CHG in sterile water; Irrisept, Innovation Technologies, Inc, Lawrenceville, Georgia) for wound irrigation.

\subsection{Clinical outcomes}

Similar to other antiseptic irrigation efficacy studies, the broad-spectrum effects of CHG have been highlighted in in vitro studies. CHG solutions have been shown to decrease MRSA biofilm load (Schwechter et al., 2011) and Staphylococcus epidermidis biofilm (Frisch et al., 2017) on orthopaedic implants using a titanium alloy (Ti-6Al-4V) in vitro models. Clinically, Barros et al. (2019) noted an $89.5 \%$ (34 out of 38) success rate using a CHG scrub brush followed by normal saline irrigation in a DAIR (12 THA, 12 TKA) protocol at 2-year follow-up. Similarly, Byren et al. (2009) used an unknown concentration and volume of CHG irrigation for the treatment of 51 TKA and 52 THA PJIs, noting a success rate of $73.1 \%$ (38 out of 51) and $86.5 \%$ (45 out of 52), respectively. There is no literature, however, to our knowledge, that explores the utility of the commercially available CHG solution alone in the definitive management of PJI. Since the commercially available solution has low CHG concentration $(0.05 \%)$, its efficacy against biofilm may be limited based on in vitro studies.

\subsection{Complications}

Although CHG has demonstrated efficacy against grampositive and gram-negative pathogens (Van Meurs et al., 2014), other studies have shown its antibacterial effect offset by increased host tissue toxicity (Liu et al., 2018). Higher CHG concentrations ( $0.5 \%$ to $2 \%$ ) have been shown to substantially reduce human fibroblast, myoblast, osteoblast, and stromal cell survival (Kavolus et al., 2020; Van Meurs et al., 2014). Furthermore, some studies report antibiotic resistance after CHG exposure, as well as Enterococcus faecium and Pseudomonas resistance to CHG itself (Kavolus et al., 2020). Hypersensitivity reactions and anaphylaxis, although rare, also remain a concern.

\section{Acetic acid}

Acetic acid, commonly found in vinegar, is a weak organic acid that lowers $\mathrm{pH}$ and exerts its bactericidal activity by diffusion through the bacterial cell membrane (Tsang et al., 2018a). It has activity against both gram-positive and gramnegative organisms in both planktonic and biofilm environ- 
ments (Kavolus et al., 2020; Tsang et al., 2018b). Similar to povidone iodine, $\mathrm{CHG}$, and hydrogen peroxide, orthopaedic implant materials such as stainless steel and titanium are resistant to its corrosive effects (Tsang et al., 2018a).

\subsection{Clinical outcomes}

Acetic acid demonstrates antibiofilm activity against Pseudomonas aeruginosa and $S$. aureus with concentrations as low as $0.5 \%$ and $1 \%$, respectively (Williams et al., 2017). Although acetic acid is noncorrosive to human tissue at concentrations less than $5 \%$ (Hughes and Webber, 2017), Tsang et al. (2018a) reported 5\% acetic acid solution eradicated $96.1 \%$ of MSSA biofilm and a $3 \%$ solution reduced MSSA biofilm by $85.9 \%$. The MBEC at 10 and 20 min was $15 \%$ and $11 \%$, respectively (Tsang et al., 2018a).

There is limited in vivo data on acetic acid's effectiveness for treating PJI. Williams et al. (2017) implemented a $20 \mathrm{~min}$ soak with $3 \%$ acetic acid during TKA PJI management using DAIR, two-stage exchange arthroplasty and arthrodesis procedures. The authors reported an $87 \%$ (20 out of 23) success rate without any host tissue toxicity resulting in wound complications. Further investigation is warranted to evaluate acetic acid's role against a broad spectrum of common PJI bacterial and fungal pathogens and its safety on surrounding host soft tissue.

\subsection{Complications}

Unlike other antiseptic solutions, $3 \%$ acetic acid requires long soaking times up to $20 \mathrm{~min}$ to have optimal concentration and duration against resistant Pseudomonas wound infections (Tsang et al., 2018a; Williams et al., 2017). The long duration of acetic acid's intraoperative application must be considered alongside the risks of increased intraoperative times to the patient.

\section{Sodium hypochlorite}

Sodium hypochlorite $(\mathrm{NaOCl})$ commercially sold as Dakin's solution (Century Pharmaceuticals, Inc, Indianapolis, Indiana), is household bleach that has antimicrobial activity against aerobic and anaerobic bacteria, viruses, and fungi at lower concentrations $(0.005 \%-0.025 \%)$, while sparing host fibroblasts and chondrocytes. Sodium hypochlorite produces chloride ions, a potent oxidizer that inhibits protein synthesis and essential lipids in the bacterial and fungal cell membrane resulting in its bactericidal and fungicidal effect (Campbell et al., 2018). Its antimicrobial activity and host cytotoxicity are time-dependent with an ability to dissolve necrotic tissue debris (Campbell et al., 2018).

\subsection{Clinical outcomes}

Despite sodium hypochlorite's utilization for centuries as an antiseptic agent, there are limited studies reporting efficacy against biofilm in PJI management. Ernest et al. (2018) compared povidone iodine, hydrogen peroxide, and sodium hypochlorite against MSSA biofilms grown in vitro on cobalt chrome (CoCr), titanium alloy (Ti), and stainless steel (SS) discs. Although all topical applications resulted in reductions in MSSA, the largest bacterial reduction was found in stainless steel implants treated with sodium hypochlorite. Further in vivo studies are needed to evaluate the role of sodiumhypochlorite solution in the treatment of PJI.

\section{Hypochlorous acid}

Hypochlorous acid ( $\mathrm{HOCl})$ is a naturally occurring molecule generated by white blood cells during the oxidative burst to kill pathogens (Block and Rowan, 2020). Similar to sodium hypochlorite, the residual chloride ions oxidize the surrounding bacterial or fungal cells in a more acidic $\mathrm{pH}$ of 5.5 (Block and Rowan, 2020). HOCl has a focal role in innate host defense with potency against drug-resistant bacteria (Block and Rowan, 2020). HOCl is commercially available as Vashe Wound Therapy Solution (SteadMed Medical LLC, Ft. Worth, Texas) as an irrigation solution marketed for the management of stasis ulcers, diabetic ulcers, and burns (Vashe, 2021).

\subsection{Clinical outcomes}

Commercially available $\mathrm{HOCl}$ has demonstrated efficacy against biofilm disruption with low cytotoxic effects (Robson, 2014). Robson (2014) investigated the efficacy of Vashe Wound Therapy Solution against $S$. aureus biofilm and found greater than $99 \%$ reduction following $1 \mathrm{~min}$ and $100 \%$ after $3,5,7$, and $10 \mathrm{~min}$ of exposure (Robson, 2014). However, Kubacki and Gilbert (2018) reported HOCl producing significant erosion and wear on cobalt chrome and titanium metals, potentially limiting its utility in DAIR procedures. Further research is needed to determine the utility of $\mathrm{HOCl}$ against common PJI pathogens, host tissue toxicity, and its role as an antiseptic irrigant in PJI management.

\section{Preformulated combination irrigant}

Bactisure Wound Lavage solution (Next Science Ltd, Jacksonville, Florida; distributed by Zimmer-Biomet, Warsaw, Indiana) is a preformulated irrigation solution that consists of ethanol, acetic acid, sodium acetate, and benzalkonium chloride in sterile water. Bactisure's mixture of surfactants, chelating agents and salts deconstruct the extracellular polymeric substance (EPS) matrix that serves as a physical barrier on bacteria and is fundamental in biofilm formation (Hunter and Duncan, 2019). Prontosan Wound Irrigation Solution 
Table 2. Preparation of most common irrigation solutions.

\begin{tabular}{|c|c|c|}
\hline Solution & Additive & Irrigation preparation \\
\hline Povidone iodine & Antiseptic & $\begin{array}{l}17.5 \mathrm{~mL} 10 \% \mathrm{PI}+500 \mathrm{cc} \text { NS } \\
\text { or } \\
\text { Surgiphor }(0.5 \%) \text { (Surgiphor Wound } \\
\text { Irrigation System FDA, 2021) }\end{array}$ \\
\hline Chlorhexidine gluconate & Antiseptic & $\begin{array}{l}\text { Irrisept }(0.05 \%) \text { (Premkumar et al., } \\
2020)\end{array}$ \\
\hline Acetic acid & Antiseptic & $\begin{array}{l}\text { Available in } 3 \% \text { concentration without } \\
\text { dilution }\end{array}$ \\
\hline Sodium hypochlorite & Antiseptic & $\begin{array}{l}\text { Dakin's solution }(0.5 \%) \\
\text { Can be further diluted with } 500 \mathrm{cc} \mathrm{NS} \\
\text { for } 0.25 \% \text { concentration }\end{array}$ \\
\hline Hypochlorous acid & Antiseptic & $\begin{array}{l}\text { Vashe Wound Therapy Solution (Vashe, } \\
\text { 2021) }\end{array}$ \\
\hline $\begin{array}{l}0.1 \% \text { polyhexamethylene biguanide } \\
0.1 \% \text { betaine }\end{array}$ & Antiseptic-surfactant combination & $\begin{array}{l}\text { Prontosan Wound Irrigation Solution } \\
\text { (B. Braun, 2021) }\end{array}$ \\
\hline $\begin{array}{l}\text { Ethanol } \\
\text { Acetic acid } \\
\text { Sodium acetate } \\
\text { Benzalkonium chloride } \\
\text { Sterile water }\end{array}$ & Antiseptic-surfactant combination & $\begin{array}{l}\text { Bactisure Wound Lavage solution (Bac- } \\
\text { tisure }\end{array}$ \\
\hline
\end{tabular}

PI: povidone iodine; NS: normal saline $0.9 \%$; L: liter; PA: Pennsylvania; GA: Georgia.

Table 3. Antiseptic combination reactions.

\begin{tabular}{llll}
\hline Antiseptic solutions & Chlorhexidine gluconate $4 \%$ & Hydrogen peroxide 3\% & Sodium hypochlorite $0.5 \%$ \\
\hline Povidone iodine $10 \%$ & Precipitate & No reaction & Gas \\
Hydrogen peroxide $3 \%$ & Precipitate & n/a & Gas \\
Sodium hypochlorite $0.5 \%$ & Precipitate, gas & Gas & n/a \\
\hline
\end{tabular}

n/a: not applicable.

Table content reproduced with permission from Campbell et al. (2018).

(B. Braun Medical Inc, Bethlehem, PA) is a commercially available combination comprised of $0.1 \%$ polyhexamethylene biguanide and $0.1 \%$ betaine (surfactant) that has been reported to have efficacy against biofilms in chronic wound ulcers (B. Braun, 2021); however, its utility in prevention or management of PJI is yet to be determined.

\subsection{Clinical outcomes}

Similar to commercially available $\mathrm{HOCl}$, Bactisure has been primarily studied for the management of skin and soft tissue infections, with inconclusive data on its efficacy in PJI. A prospective, multi-center single-arm study recently concluded that studied the role of Bactisure in TKA PJI and compared preoperative and postoperative aspiration fluid cell counts after articular irrigation with Bactisure in TKA PJI. Since the investigation recently finished, the study's findings and relevancy are unknown. Further studies are needed before a conclusive recommendation can be made on its use in PJI. The preparation of the most common antiseptic irrigation solutions is summarized in Table 2.

\section{Complications of antiseptic solution combinations}

Although the combination of antiseptic solutions has demonstrated synergistic bactericidal effects and broader antibacterial coverage, it is important to note that not all irrigants should be used concomitantly; $1 \%$ povidone iodine, $0.25 \%$ acetic acid, $3 \%$ hydrogen peroxide, and $0.5 \%$ sodium hypochlorite have demonstrated substantial host cytotoxicity, especially when used together (Lineaweaver et al., 1985). A $10 \%$ povidone-iodine solution combined with $4 \%$ CHG has been reported to result in precipitates. Similarly, a $10 \%$ 
Table 4. Antiseptic irrigation protocols in the literature.

\begin{tabular}{|c|c|c|c|c|}
\hline Study & Antiseptics & Protocol & Success Rate & $\mathrm{LOE}^{\mathrm{a}}$ \\
\hline Williams et al. (2017) & AA $3 \%$ & $\begin{array}{l}\text { Surgical debridement } \rightarrow \text { modular com- } \\
\text { ponent exchange } \rightarrow 20 \text { min AA soak } \\
\rightarrow \text { NS irrigation }\end{array}$ & $\begin{array}{l}86.9 \%(20 / 23) \\
\text { months }\end{array}$ & Therapeutic Level II \\
\hline Byren et al. (2009) & $\mathrm{CHG}^{\mathrm{b}}$ & $\begin{array}{l}\text { Surgical debridement } \rightarrow \text { modular com- } \\
\text { ponent exchange } \rightarrow \mathrm{CHG}^{\mathrm{b}, \mathrm{c}} \text { pulse } \\
\text { lavage }\end{array}$ & $\begin{array}{l}73.1 \%(38 / 51) \text { TKA } \\
86.5 \%(45 / 52) \text { THA at } 2.3 \\
\text { years }\end{array}$ & Therapeutic Level III \\
\hline Barros et al. (2019) & $\mathrm{CHG}^{\mathrm{b}}$ & $\begin{array}{l}\text { Surgical debridement } \rightarrow 3 \mathrm{~L} \mathrm{CHG}^{\mathrm{b}} \text { irri- } \\
\text { gation } \rightarrow 3 \mathrm{~L} \mathrm{NS} \text { irrigation } \rightarrow \text { re-drape } \\
\rightarrow 1 \mathrm{~L} \mathrm{NS} \text { irrigation } \rightarrow \text { modular com- } \\
\text { ponent exchange }\end{array}$ & $\begin{array}{l}89.5 \%(34 / 38) \mathrm{TKA} / \mathrm{THA} \text { at } \\
3.5 \text { years }\end{array}$ & Therapeutic Level III \\
\hline Hart et al. (2019) & PI $0.25 \%$ & $\begin{array}{l}\text { Surgical debridement } \rightarrow 1 \text { L PI } 0.25 \% \\
3 \text { min soak } \rightarrow \text { NS irrigation }\end{array}$ & $\begin{array}{l}\text { TKA: } \\
96.8 \%(487 / 503) \text { at } 3 \text { months } \\
93.4 \%(298 / 319) \text { at } 12 \text { months } \\
\text { THA: } \\
96.3 \%(367 / 381) \text { at } 3 \text { months } \\
94.8 \%(219 / 231) \text { at } 12 \text { months }\end{array}$ & Therapeutic Level III \\
\hline Kim et al. (2015) & PI $10 \%$ & $\begin{array}{l}\text { Surgical debridement } \rightarrow 3-6 \mathrm{~L} \text { NS } \\
\text { pulse lavage } \rightarrow \text { modular component ex- } \\
\text { change versus head and liner replace- } \\
\text { ment after } 10-15 \text { min } 97 \% \text { ethanol soak } \\
\rightarrow \text { PI } 10 \% \text { soak } 5-10 \text { min } \rightarrow 3 \text { L NS ir- } \\
\text { rigation }\end{array}$ & $100 \%$ THA at 1 year & Therapeutic Level III \\
\hline Riesgo et al. (2018) & PI $0.35 \%$ & $\begin{array}{l}\text { Surgical debridement } \rightarrow \text { modular com- } \\
\text { ponent exchange } \rightarrow 500 \mathrm{~mL} \text { PI } 0.35 \% \\
\text { bulb irrigation } \rightarrow 1 \mathrm{~L} \text { NS pulse lavage } \\
\rightarrow 1 \mathrm{~g} \text { Vancomycin deep to fascia, } 1 \mathrm{~g} \\
\text { Vancomycin superficial }\end{array}$ & $\begin{array}{l}\text { TKA: } 75 \%(12 / 16) \text { THA: } 90 \% \\
(8 / 10) \\
\text { All at } 1 \text { year }\end{array}$ & Therapeutic Level III \\
\hline George et al. (2015) & $\begin{array}{l}\mathrm{PI} 10 \% \\
\mathrm{H}_{2} \mathrm{O}_{2} 1.5 \%\end{array}$ & $\begin{array}{l}\text { Surgical debridement } \rightarrow \text { explantation } \\
\rightarrow 12 \mathrm{~L} \text { warm NS pulse lavage } \rightarrow \\
100 \mathrm{~mL} \mathrm{H}_{2} \mathrm{O}_{2} 3 \% \text { in } 100 \mathrm{~mL} \text { of ster- } \\
\text { ile water irrigation } \rightarrow \mathrm{NS}^{\mathrm{c}} \text { irrigation } \rightarrow \\
200 \mathrm{~mL} \text { PI } 10 \% \text { irrigation } \rightarrow \text { PI } 10 \% \\
\text { soaked gauze in wound for re-drape } \rightarrow \\
200 \mathrm{~mL} \text { PI } 10 \% \text { irrigation } \rightarrow 1 \mathrm{~L} \mathrm{NS} \\
\text { pulse lavage } \rightarrow \text { component implanta- } \\
\text { tion } \rightarrow 1 \mathrm{~L} \mathrm{NS} \text { irrigation }\end{array}$ & $\begin{array}{l}100 \%(5 / 5 \text { THA at } 5 \text { years; } \\
28 / 28 \text { TKA at } 6.5 \text { years })\end{array}$ & Therapeutic Level II \\
\hline Haddad et al. (2015) & $\begin{array}{l}\mathrm{PI}^{\mathrm{b}} \\
\mathrm{H}_{2} \mathrm{O}_{2}^{\mathrm{b}}\end{array}$ & $\begin{array}{l}\text { Surgical debridement } \rightarrow \text { explantation } \\
\rightarrow \mathrm{PI}^{\mathrm{b}, \mathrm{c}} \text { and } \mathrm{H}_{2} \mathrm{O}_{2}^{\mathrm{b}, \mathrm{c}} \text { irrigations } \rightarrow \\
\mathrm{PI}^{\mathrm{b}, \mathrm{c}} \text { soak } \rightarrow \text { re-drape } \rightarrow \text { "lavage" } \rightarrow \\
\text { component implantation }\end{array}$ & $\begin{array}{l}\text { One-Stage: } 100 \%(28 / 28) \text { at } 3 \\
\text { years } \\
\text { Two-Stage: } 93.2 \%(69 / 74) \text { at } 3 \\
\text { years }\end{array}$ & Therapeutic Level III \\
\hline Royo et al. (2013) & $\begin{array}{l}\mathrm{PI}^{\mathrm{b}} \\
\mathrm{H}_{2} \mathrm{O}_{2}^{\mathrm{b}}\end{array}$ & $\begin{array}{l}\text { Surgical debridement } \rightarrow \text { " } 9 \mathrm{~L} \mathrm{NS}, \mathrm{PI}^{\mathrm{b}} \text {, } \\
\mathrm{H}_{2} \mathrm{O}_{2}^{\mathrm{b}} \text { irrigation" } \rightarrow \text { modular compo- } \\
\text { nent exchange } \rightarrow \text { drain with continuous } \\
\mathrm{NS} \text { irrigation for } 24 \mathrm{~h}(6 \mathrm{~L} / \mathrm{d} \text { rate })\end{array}$ & $\begin{array}{l}73.5 \% \quad(25 / 34) \\
\text { months }\end{array}$ & Therapeutic Level III \\
\hline Duque et al. (2017) & $\begin{array}{l}\text { Bacitracin } \\
\mathrm{PI}^{\mathrm{b}} \\
\mathrm{SH}^{\mathrm{b}}\end{array}$ & $\begin{array}{l}\text { Surgical debridement } \rightarrow \text { modular com- } \\
\text { ponent explantation } \rightarrow 3 \mathrm{~L} \mathrm{PI} \text { irri- } \\
\text { gation } \rightarrow \mathrm{PI}^{\mathrm{b}} \text { scrub brush mechani- } \\
\text { cal scrub } \rightarrow 3 \mathrm{~L} \mathrm{SH}^{\mathrm{b}} \text { irrigation } \rightarrow 3 \mathrm{~L} \\
\text { Bacitracin }{ }^{\mathrm{b}} \text { irrigation } \rightarrow 3 \mathrm{~L} \text { NS irriga- } \\
\text { tion } \rightarrow \text { re-drape } \rightarrow \text { component implan- } \\
\text { tation }\end{array}$ & $\begin{array}{l}69 \%(46 / 67) \text { TKA } \\
85 \% \text { excluding MRSA infec- } \\
\text { tions }\end{array}$ & Therapeutic Level III \\
\hline
\end{tabular}

${ }^{a}$ Marx et al. (2015).

b Concentration not specified.

${ }^{\mathrm{c}}$ Volume not specified.

LOE: level of evidence, MRSA: methicillin-resistant staphylococcus aureus, NS: normal saline, PI: povidone iodine, PJI: periprosthetic joint infection,

SH: sodium hypochlorite, THA: total hip arthroplasty, TKA: total knee arthroplasty. 
Table 5. Grades of recommendation for irrigation fluids in the management of periprosthetic joint infection.

\begin{tabular}{lll}
\hline Additives & Grade of recommendation* & Recommendation \\
\hline Surfactants & B & Should not be added to irrigation \\
Antibiotics & A & Should not be added to irrigation \\
Antiseptics & C & May be added, but studies are too mixed to determine an optimal antiseptic \\
\hline
\end{tabular}

* According to Wright (2006), grade A indicates good evidence (Level I studies with consistent findings) for or against recommending intervention; grade B, fair evidence (Level II or III studies with consistent findings) for or against recommending intervention; grade C, poor-quality evidence (Level IV or V studies with consistent findings) for or against recommending intervention; and grade I, insufficient or conflicting evidence not allowing a recommendation for or against intervention.

Table content reproduced with permission from Kavolus et al. (2020).

povidone-iodine solution combined with $7.5 \mathrm{cc}$ of $0.5 \%$ sodium hypochlorite has also resulted in both a precipitate and gas product. While the combination of hydrogen peroxide and povidone iodine does not form a precipitate or gas, a $3 \%$ hydrogen-peroxide solution mixture with $4 \% \mathrm{CHG}$ forms precipitates and potentially harmful gas when mixed with $0.5 \%$ sodium hypochlorite (Campbell et al., 2018). The effect of precipitates and gas products, however, has yet to be determined.

Particular care must be heeded when combining $\mathrm{CHG}$ with other antiseptics, as it can form a precipitate with sodium hypochlorite, $3 \%$ hydrogen peroxide, and $10 \%$ povidone iodine (Campbell et al., 2018). It also forms a potentially flammable and carcinogenic gaseous byproduct when combined with sodium hypochlorite (Campbell et al., 2018). Surgeons should exercise caution while using multiple irrigating solutions and consider adding meticulous irrigation with normal saline between the use of varying antiseptic irrigation solutions (Table 3). Finally, it should be noted that although multiple irrigants are utilized for PJI, the current available antiseptic solutions are not FDA-approved, aside from Bactisure, to be used internally and are reserved for external use only.

\section{Conclusion}

This general overview provides the most up-to-date review of the available literature on irrigation solutions used in PJI. While basic science studies assist in the selection of irrigation fluids, in vitro results do not directly translate into clinical significance once implemented in vivo. Direct comparison of different irrigation solutions remains difficult because of variability in treatment protocols (Table 4). The current commercially available antiseptic irrigants all have potential against a broad spectrum of PJI pathogens with their own unique advantages and disadvantages (Table 5). PI, CHG, hydrogen peroxide, acetic acid, Dakin's solution are all cost-effective options with noteworthy in vitro bactericidal properties. It is important to consider that although solutions used in combinations demonstrate excellent efficacy against common pathogens in vitro, there is inconclusive data on in vivo efficacy and complications related to the observed byproducts. It is also important to be aware that many of the current available antiseptic solutions are not FDA-approved for internal use. Commercially preformed irrigants are FDA-approved wound lavage solutions that have shown early promise; however, the increased cost and role in the management of definitive PJI treatment is yet to be determined. Therefore, there are currently no clear recommendations regarding the optimal irrigation solution for management of acute or chronic infections. Future clinical studies are needed to identify the ideal irrigation solution(s) with optimal bactericidal properties and low cytotoxicity for PJI treatment.

Data availability. No data sets were used in this article.

Author contributions. AS and ZEA designed the paper and carried out the data collection and paper writing and editing. AFC and BDS aided in data collection and paper editing.

Competing interests. Ahmed Siddiqi is an unpaid consultant for AZ Solutions, LLC; has stock options in ROMTech; and is a paid consultant for Zimmer-Biomet. The Bactisure Wound Lavage solution is discussed in the paper.

Zuhdi E. Abdo has no disclosures or conflict of interest.

Bryan D. Springer is a board member of the Knee Society, AJRR, AAHKS, Arthroplasty Today, and Journal of Arthroplasty; a paid consultant for Ceramtec, Convatec, Joint Purifications Systems, OsteoRemedies; and receives royalties from Stryker. These are not relevant for this paper.

Antonia F. Chen is a board member of AAOS, AJRR, AAHKS, Annals of Joint, CORR, the European Knee Association, Healthcare Transformation ICJR, JOA, JBJI, JBJS, JOR, KSSTA, and MSIS; receives royalties; and is a paid consultant for AMA, Convatec, Ethicon, GLG, Graftworx, Guidepoint, Heraeus, Hyalex, Irrimax, Joint Purification Systems, Pfizer, PhagoMed, Recro, SLACK Incorporated, Sonoran, Stryker, and UpToDate. The Irrisept solution is discussed in the paper.

Review statement. This paper was edited by Parham Sendi and reviewed by two anonymous referees. 


\section{References}

Bactisure $^{\mathrm{TM}}$ : Surgical Lavage - NextScience, available at: https: //www.nextscience.com/bactisure-surgical-lavage/, last access: 6 January 2021.

Barros, L. H., Barbosa, T. A., Esteves, J., Abreu, M., Soares, D., and Sousa, R.: Early Debridement, antibiotics and implant retention (DAIR) in patients with suspected acute infection after hip or knee arthroplasty - safe, effective and without negative functional impact, J. Bone Joint Infect., 4, 300-305, https://doi.org/10.7150/jbji.39168, 2019.

B. Braun: Prontosan ${ }^{\circledR}$ Irrigation Solution, available at: https://www. bbraunusa.com/en/products/b4/prontosan-irrigationsolution. html, last access: 1 May 2021.

Block, M. S. and Rowan, B. G.: Hypochlorous acid: a review, J. Oral Maxillofacial Surg., 78, 1461-1466, 2020.

Blom, A., Cho, J., Fleischman, A., Goswami, K., Ketonis, C., Kunutsor, S. K., Makar, G., Meeker, D. G., Morgan-Jones, R., Ortega-Peña, S., Parvizi, J., Smeltzer, M., Stambough, J. B., Urish, K., and Ziliotto, G.: General Assembly, Prevention, Antiseptic Irrigation Solution: Proceedings of International Consensus on Orthopedic Infections, J. Arthroplasty, 34, S131-S138, 2019.

Byren, I., Bejon, P., Atkins, B. L., Angus, B., Masters, S., McLardySmith, P., Gundle, R., and Berendt, A.: One hundred and twelve infected arthroplasties treated with "DAIR" (debridement, antibiotics and implant retention): antibiotic duration and outcome, J. Antimicrob. Chemoth., 63, 1264-1271, 2009.

Campbell, S. T., Goodnough, L. H., Bennett, C. G., and Giori, N. J.: Antiseptics Commonly Used in Total Joint Arthroplasty Interact and May Form Toxic Products, J. Arthroplasty, 33, 844-846, 2018.

Cichos, K. H., Andrews, R. M., Wolschendorf, F., Narmore, W., Mabry, S. E., and Ghanem, E. S.: Efficacy of Intraoperative Antiseptic Techniques in the Prevention of Periprosthetic Joint Infection: Superiority of Betadine, J. Arthroplasty, 34, S312-S318, 2019.

Duque, A. F., Post, Z. D., Lutz, R. W., Orozco, F. R., Pulido, S. H., and Ong, A. C.: Is there still a role for irrigation and debridement with liner exchange in acute periprosthetic total knee infection?, J. Arthroplasty, 32, 1280-1284, 2017.

Ernest, E. P., Machi, A. S., Karolcik, B. A., LaSala, P. R., and Dietz, M. J.: Topical adjuvants incompletely remove adherent Staphylococcus aureus from implant materials, J. Orthop. Res., 36, 1599 1604, 2018.

FDA: FDA requests withdrawal of bacitracin for injection from market, FDA, available at: https: //www.fda.gov/drugs/drug-safety-and-availability/ fda-requests-withdrawal-bacitracin-injection-market

(last access: 12 January 2021), 2020.

Foresman, P. A., Donyll Payne, B. S., Daniel Becker, L., Lewis, D., and Rodeheaver, G. T.: A Relative Toxicity Index for Wound Cleansers, 5, 226-231, 1993.

Frisch, N. B., Kadri, O. M., Tenbrunsel, T., Abdul-Hak, A., Qatu, M., and Davis, J. J.: Intraoperative chlorhexidine irrigation to prevent infection in total hip and knee arthroplasty, Arthroplasty Today, 3, 294-297, 2017.

George, D. A., Konan, S., and Haddad, F. S.: Single-Stage Hip and Knee Exchange for Periprosthetic Joint Infection, J, Arthroplastym 30, 2264-2270, 2015.
George, J., Klika, A. K., and Higuera, C. A.: Use of Chlorhexidine Preparations in Total Joint Arthroplasty, J. Bone Joint Infect., 2, 15-22, https://doi.org/10.7150/jbji.16934, 2017.

Gilotra, M., Nguyen, T., Jaffe, D., and Sterling, R.: Dilute betadine lavage reduces implant-related bacterial burden in a rabbit knee prosthetic infection model, Am. J. Orthop., 44, E38-E41, 2016, 2015.

Glynn, A. A., O’Donnell, S. T., Molony, D. C., Sheehan, E., McCormack, D. J., and O'Gara, J. P.: Hydrogen peroxide induced repression of icaADBC transcription and biofilm development in staphylococcus epidermidis, J. Orthop. Res., 27, 627-630, 2009.

Goswami, K. and Austin, M. S.: Intraoperative povidone-iodine irrigation for infection prevention, Arthroplasty Today, 5, 306-308, 2019a.

Goswami, K. and Austin, M. S.: Intraoperative povidone-iodine irrigation for infection prevention, Arthroplasty Today, 5, 30-308, 2019b.

Goswami, K., Cho, J., Foltz, C., Manrique, J., Tan, T. L., Fillingham, Y., Higuera, C., Della Valle, C., and Parvizi, J.: Polymyxin and Bacitracin in the Irrigation Solution Provide No Benefit for Bacterial Killing in Vitro, J. Bone Joint Surg. Am., 101, 16891697, 2019.

Haddad, F. S., Sukeik, M., and Alazzawi, S.: Is single-stage revision according to a strict protocol effective in treatment of chronic knee arthroplasty infections?, Clin. Orthop. Relat. Res., 473, 8 14,2015

Hart, A., Hernandez, N. M., Abdel, M. P., Mabry, T. M., Hanssen, A. D., and Perry, K. I.: Povidone-iodine wound lavage to prevent infection after revision total hip and knee arthroplasty: an analysis of 2884 cases, J. Bone Joint Surg. Am., 101, 1151-1159, 2019.

Henley, N., Carlson, D. W. A., Kaehr, D. M., \& Clements, B. Air Embolism Associated with Irrigation of External Fixator Pin Sites with Hydrogen Peroxide: A Report of Two Cases, J. Bone Joint Surg. Am., 86, 821-822, 2004.

Hughes, G. and Webber, M. A.: Novel approaches to the treatment of bacterial biofilm infections, Brit. J. Pharmacol., 174, 22372246, 2017.

Hunter, C. and Duncan, S.: Clinical Effectiveness of a Biofilm Disrupting Surgical Lavage in Reducing Bacterial Contamination in Total Knee Arthroplasty Revision Surgery in Known Cases of Prosthetic Joint Infection, available at: https://www.zimmerbiomet.com/content/dam/ zimmer-biomet/medical-professionals/surgical-and-cement/ bactisure-wound-lavage/2656.1\%20US-en\%20Bactisure\% 20White\%20Paper.pdf (last access: 10 May 2021), 2019.

Kavolus, J. J., Schwarzkopf, R., Rajaee, S. S., and Chen, A. F.: Irrigation Fluids Used for the Prevention and Treatment of Orthopaedic Infections, J. Bone Joint Surg. Am., 102, 76-84, 2020.

Kim, J. H., Rimmer, J., Mrad, N., Ahmadzada, S., and Harvey, R. J.: Betadine has a ciliotoxic effect on ciliated human respiratory cells, J. Laryngol. Otol., 129, S45-50, 2015.

Kubacki, G. W. and Gilbert, J. L.: The effect of the inflammatory species hypochlorous acid on the corrosion and surface damage of Ti-6Al-4V and CoCrMo alloys, J. Biomed. Mater. Res. A, 106, 3185-3194, 2018.

Lineaweaver, W., Howard, R., Soucy, D., McMorris, S., Freeman, J., Crain, C., Robertson, J., and Rumley, T.: Topical Antimicrobial Toxicity, Arch. Surg., 120, 267-270, 1985. 
Liu, J. X., Werner, J., Kirsch, T., Zuckerman, J. D., and Virk, M. S.: Cytotoxicity evaluation of chlorhexidine gluconate on human fibroblasts, myoblasts, and osteoblasts, J. Bone Joint Infect., 3, 165-172, https://doi.org/10.7150/jbji.26355, 2018.

Lu, M. and Hansen, E. N.: Hydrogen Peroxide Wound Irrigation in Orthopaedic Surgery, J. Bone Joint Infect., 2, 3-9, https://doi.org/10.7150/jbji.16690, 2017.

Marx, R. G., Wilson, S. M., and Swiontkowski, M. F.: Updating the Assignment of Levels of Evidence, Journal Bone Joint Surg., 97, $1-2$, doi10.2106/JBJS.N.01112, 2015.

Premkumar, A., Nishtala, S., Bostrom, M. P., and Carli, A.: InVitro Analysis of Anti-Biofilm Effect of Intraoperative Irrigation Solutions, AAHKS, 2020.

Rabenberg, V. S., Ingersoll, C. D., Sandrey, M. A., and Johnson, M. T.: The bactericidal and cytotoxic effects of antimicrobial wound cleansers, J. Athl. Training, 37, 51-54, 2002.

Riesgo, A. M., Park, B. K., Herrero, C. P., Yu, S., Schwarzkopf, R., and Iorio, R.: Vancomycin Povidone-Iodine Protocol Improves Survivorship of Periprosthetic Joint Infection Treated With Irrigation and Debridement, J. Arthroplasty, 33, 847-850, 2018.

Robson, M.: Treating Chronic Wounds With Hypochlorous Acid Disrupts Biofilm, Today's Wound Clinic, 8, 2014.

Royo, A., Bertrand, M. L., Ramos, L., Fernandez-Gordillo, F., and Guerado, E.: Is there still a place for continuous closed irrigation in the management of periprosthetic total knee infection?, Open Orthop. J., 7, 205-210, 2013.

Ruder, J. A. and Springer, B. D.: Treatment of Periprosthetic Joint Infection Using Antimicrobials: Dilute Povidone-Iodine Lavage, J. Bone Joint Infect., 2, 10-14, https://doi.org/10.7150/jbji.16448, 2017.

Schwechter, E. M., Folk, D., Varshney, A. K., Fries, B. C., Kim, S. J., and Hirsh, D. M.: Optimal irrigation and debridement of infected joint implants: An in vitro methicillin-resistant staphylococcus aureus biofilm model, J. Arthroplasty, 26, 109-113, 2011.

Sloan, M., Premkumar, A., and Sheth, N. P.: Projected volume of primary total joint arthroplasty in the u.s., 2014 to 2030, J. Bone Joint Surg. Am., 100, 1455-1460, 2018.
Surgiphor Wound Irrigation System FDA: available at: https:// www.accessdata.fda.gov/cdrh_docs/pdf20/K202071.pdf, last access: 1 May 2021.

Tsang, S. T. J., Gwynne, P. J., Gallagher, M. P., and Simpson, A. H. R. W.: The biofilm eradication activity of acetic acid in the management of periprosthetic joint infection, Bone Joint Res., 7, 517-523, https://doi.org/10.1302/2046-3758.78.BJR2018-0045.R1, 2018a.

Tsang, S. T. J., Gwynne, P. J., Gallagher, M. P., and Simpson, A. H. R. W.: The biofilm eradication activity of acetic acid in the management of periprosthetic joint infection, Bone Joint Res., 7, 517-523, https://doi.org/10.1302/2046-3758.78.BJR2018-0045.R1, 2018b.

Van Meurs, S. J., Gawlitta, D., Heemstra, K. A., Poolman, R. W., Vogely, H. C., and Kruyt, M. C.: Selection of an optimal antiseptic solution for intraoperative irrigation: An in vitro study, J. Bone Joint Surg. Am., : 96, 285-291, 2014.

Vashe: Urgo Medical North America, available at: http://www. steadmed.com/vashe/, last access: 1 May 2021.

Waran, K. D. and Munsick, R. A.: Anaphylaxis from povidoneiodine, The Lancet, 345, 1506, https://doi.org/10.1016/S01406736(95)91063-8, 1995.

Weinstein, R. A., Milstone, A. M., Passaretti, C. L., and Perl, T. M.: Chlorhexidine: Expanding the Armamentarium for Infection Control and Prevention, Clin. Infect. Dis., 46, 274-281, 2008.

Williams, R. L., Ayre, W. N., Khan, W. S., Mehta, A., and MorganJones, R.: Acetic Acid as Part of a Debridement Protocol During Revision Total Knee Arthroplasty, J. Arthroplasty, 32, 953-957, 2017.

World Health Organization: WHO Global guidelines for the prevention of surgical site infection, WHO, 6-7, 2018.

Wright, J. G.: Revised grades of recommendation for summaries or reviews of orthopaedic surgical studies, J. Bone Joint Surg. Am., 88, 1161-1162, 2006.

Zubko, E. I. and Zubko, M. K.: Co-operative inhibitory effects of hydrogen peroxide and iodine against bacterial and yeast species, BMC Research Notes, 6, 272, https://doi.org/10.1186/17560500-6-272, 2013. 